\section{"There are not enough hours in a day to do everything": Parents' descriptions of everyday life with a child with severe physical disability}

Häyrynen, Eija

Valteri Centre for Learning and Consulting, Finland (eija.hayrynen@valteri.fi)

Määttä, Kaarina

University of Lapland, Finland (Kaarina.Maatta@ulapland.fi)

Äärelä, Tanja

University of Lapland, Finland (Tanja.Aarela@ulapland.fi)

Uusiautti, Satu $\measuredangle$

University of Lapland, Finland (atu.Uusiautti@ulapland.fi)

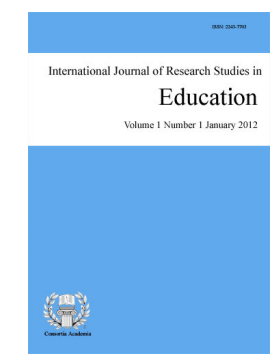

ISSN: 2243-7703 Online ISSN: 2243-7711

OPEN ACCESS

\title{
Abstract
}

Life in families with a child with a severe physical disability is filled with various demands and needs for extraordinary solutions. The purpose of this research was to investigate how parents describe their everyday life, coping, and solutions regarding parenting. The research question set for this study was "How do the parents of a child with severe physical disability describe their everyday life?" The research participants were the parents of 120 students with severe physical disability participating the remedial courses at Tervaväylä Special Education School in Oulu, Finland. Their parents described their everyday challenges and joys openly which are introduced as findings in this article. Parents' work, societal demands, and the child's special needs together are burdening and creating a daily structure that is functional requires time and effort from parents. Ability to be flexible and trust in positive development in the child and multi-professional collaboration are the keys to coping. In addition, parents emphasized the ability to find joy from small successes and steps in their child's progress.

Keywords: parenthood; severe physical disability; home; upbringing; special needs; everyday life 


\section{"There are not enough hours in a day to do everything": Parents' descriptions of everyday life with a child with severe physical disability}

\section{Introduction}

Good parenthood has been characterized in numerous ways (e.g. Petersson, Petersson, \& Håkansson, 2004). While the foci have changed over the course of time, there has been something permanent in the fundamentals of parenthood (Bailey, 2014). Parents provide children with home, care, safety, and irreplaceable premises for good life and well-being. Children's individual characteristics set their own preconditions for upbringing, and therefore, raising a child is not always just easy and joyful (Määttä \& Uusiautti, 2012). Today's parents have all kinds of pressures that originate in employment, economic aspects, the division of domestic labor, the professionalization of upbringing, and so on (Clark, 2000; Fuchs, 2004).

Parents' versatile roles have been studied abundantly (Määttä \& Uusiautti, 2012). Parents can have the roles of a teacher of life, an expert in human relationships, a love giver, a limit setter, and a caregiver (e.g., Veríssimo et al., 2011; Määttä \& Uusiautti, 2012). Bert, Farris, and Borkowski (2008) refer to five principles that create the basis of good parenthood: responding, preventing, monitoring, mentoring, and modeling.

The classic attachment theory by Bowlby (1973) emphasized how a secure attachment reflects on the child's ability to create and maintain reciprocal relationships in life. Indeed, a secure attachment is important for development because it protects from emotional and behavioral problems, strengthens resilience, and promotes the ability to create good relationships without being suspicious or reserved. Parents' emotional skills and abilities to respond to children's needs for care enhance the sense of security in children (Brannan \& Heflinger, 2002; Guest \& Keating, 2009). However, everyday life in a home where the child has severe physical disability may become especially challenging for parents (Starke \& Möller, 2002; Tudge, 2008). Parents are targeted with great expectations (Swain \& Cameron, 2003) and may have to look for special solutions to cope with their everyday life (Beresford, 1996). Telling about these solutions and daily challenges is not necessarily easy (Bernheimer \& Weisner, 2007). In this article, we analyze parents' descriptions and experiences of life with children with severe physical disability. How do they handle upbringing, schooling, and daily chores?

\section{Challenges in parenting a child with severe physical disability}

Most parents become to know already before their child is born that their child will born with physical disability (Graungaard \& Skov, 2007). Previous studies show that parents usually adopt the situation well even though their everyday lives change drastically and they will have new kinds of parenting challenges (Hassal \& Rose, 2005). Apparently, parents can focus on their child's individual needs instead of the disability (Rentnick et al., 2009). In addition, parents develop various methods to meet the challenges caused by their child's disability (Glidden \& Natcher, 2009).

Still, the child's disability undeniably has influence on the everyday life at home and parenthood (Cen \& Aytac, 2017). In addition to physical disability, parents may have to face disruptive behaviors (Plant \& Sanders, 2007) and difficult child temperament daily (Bailey et al., 2000). Children with physical disability need support of various kinds at home (Häyrynen, Määttä, \& Uusiautti, 2018). Many of them need wheelchairs to move around (Moat et al., 2013; Nereo \& Hinton, 2003). In addition to orthopedic challenges (Miller \& Bachrach, 2006), physical disabilities may involve additional problems that may occur, for example, as difficulties in linguistic skills (Hinton et al., 2004), movement control (Pirilä et al., 2011), sleeping (Mol et al., 2012), and oral-motor functioning (Bell et al., 2010).

Some studies have highlighted that parents who have children with physical disability are more stressed and 
strained than parents who have so-called normal children (Singer, 2006; Veisson, 1999). These findings are somewhat problematic, and for example, Smith, Oliver, and Innocenti's (2001) research did not support this notion on parents' stress.

The level of stress in parenting has been explained with the inside-family functions, resources, and available social support. For example, social interactions in families with children with physical disability become more difficult and often these families have more financial problems than do other families (e.g., Emerson et al., 2006). Parenting also means a long-term responsibility over a child, and continues past the childhood. Therefore, parenthood should be viewed across the course of life (Seltzer et al., 2001). Parents' support may be needed still in adulthood, because people with disabilities are more likely to remain single over time, although there is less evidence for any differences in rates of relationship breakdown for those who enter them (Shandra \& Penner, 2017).

Not only children with disability but also their parents may become stigmatized and become alienated from their communities (Cassidy et al., 2008). Family as a supporter of proximity and individuality within the complex modern life is significant both for children and parents. Parents should be happy about and grateful for small mercies in everyday life. That may become increasingly important in the insecure modern life and can be the crucial to children who are learning how to find their place in the world.

Negative attitudes toward disabilities (Green, 2003; 2007), difficulties in getting support (Nowak, 2017), and problems with interaction with professionals can increase parents' stress (Summers et al., 2007) and lower their well-being (see Miodrag \& Hodapp, 2010; Singer, 2006). Still it is important to point out that most parents adjust to the challenges in parenting of a child with physical disability well (Emerson et al., 2006; Hassal \& Rose, 2005).

Wallander and Varni (1998) have noticed that adjustment to parenthood and parenting a child with severe physical disability have certain risk and resilience factors. They are dependent on the severity of disability and required level of care as well as parents abilities. In addition, availability of formal and informal support determine the success of parenting. Basic positive attitudes (Hasting \& Taunt, 2002; Määttä \& Uusiautti, 2012; 2013) and belief in one's own coping (Hastings \& Brown, 2002) form the cornerstones of upbringing and explain how parents adopt their role as parents of a child with physical disability.

When it comes to upbringing of a child with physical disability, challenges in communication (see e.g., De Bortoli et al., 2010; Wadnerkar et al., 2012), attention, memory, and visual processing (e.g., Majnemer et al., 2010) necessitate special solutions. They need support especially in creating social relationships (e.g., Bennet \& Hay, 2007; Diamond \& Hong, 2010). What is the goal of upbringing and what are parents' tasks when the responsibility is shared with many educational institutions and professionals? Parenthood is not a profession but, at its best, upbringing offers a positive environment that enhances the strengths of child with severe physical disability.

\section{Method}

The purpose of this research was to find out how parents themselves describe their everyday life, coping, and solutions regarding parenting. We were interested in hearing what their practical experiences. The research question set for this study was the following:

$>\quad$ How do the parents of a child with severe physical disability describe their everyday life?

The research participants were the parents of 120 students with severe physical disability participating the remedial courses at Tervaväylä Special Education School in Oulu, Finland. Tervaväylä school arranges remedial courses of various lengths to students with severe physical disabilities in the form of multiprofessional activities. It is one of the six units of the national Valteri Centre for Learning and Consulting. Valteri is taken care of by the 
Häyrynen, E., Määttä, K., Äärelä, T., \& Uusiautti, S.

Finnish National Board of Education.

The core task of this school is to support the principle of being able to attend one's neighboring school in the northern Finland by providing education, learning materials, guidance, and remedial courses. The latter means periods that students, who usually attend school in their home counties, spend at Tervaväylä to find pedagogical methods that support their individual learning, to evaluate their remedial needs, and to assess their needs for aids and functionality of their aids. In addition to students themselves, the multiprofessional team covers the personnel from students' own schools, guardians, therapists, and special teachers and other personnel responsible for remedial courses at Tervaväylä.

The children who attended remedial training had permanent physical disabilities. Some of the students attended the course twice, some only once during the school year. Of these 120 students, 63 (52\%) were boys and $57(48 \%)$ were girls. Most of them $(\mathrm{N}=77)$ had $\mathrm{CP}$ while 20 of them had MMC. Other 15 had various disabilities, including muscular dystrophy. Hearing parents' experiences and needs makes an important part of remedial training. The purpose is to help parents cope better at home and with daily chores.

For this research, a permission to conduct the research was formally applied from the board of Tervaväylä Special Education School. Dr. Häyrynen was given the permission to familiarize with the students' background information and use this as research data. In the background information forms, parents had described widely their children's remedial training, aids, physical and mental well-being, special needs, and daily practices. They were also prompted to tell about their experiences from day care and school.

The data analysis followed qualitative content analysis (e.g., Mayring, 2000; Stamann et al., 2016). The data were reduced and categorized into themes. The purpose was to highlight the most important notions that parents brought up regarding their everyday lives. Eventually, the main themes were cut into two: the challenges and joys in everyday life. Under these themes, it was possible to find categories that best represented notions that the parents highlighted in the data. In the Results section, excerpts from the data are presented alongside interpretations of findings. Parents are separated with codes that show the special section in data.

\section{Results: Everyday life as described by parents of a child with severe physical disability}

The child who has severe physical disability needs constant help and care. Their parents described their everyday lives in many ways. The descriptions could be divided into roughly two themes of challenges and joys of daily life.

\subsection{Challenges}

In the data, the daily challenges could be categorized into four main items: (1) need for help, guidance, and monitoring of the child with severe physical disability; (2) concern over the child's well-being and lack of time; (3) concern over parents' own coping; and (4) insufficient societal services and deficiencies in the family's physical environment.

First of all, the parents described how much their children needed help in daily chores. The need for assistance determined their everyday lives widely.

"The child is doing good, everyday life goes well, needs help in getting dressed and a little bit on bathing." (parent AM/804)

Parents had to help children with homework because of, for example, difficulties in using hands, changes in activity levels, or learning difficulties. At its worst, doing homework could take the whole evening:

"Doing homework took dad the whole night, which is not good in the long run." (parent, $\mathrm{AM} / 1365)$ 
There are not enough hours in a day to do everything: Descriptions of everyday life with a child with disability

Although some children did some progress, certain difficulties were still visible and apparent:

"Reading is troublesome. Reading position is often lousy. Does homework more independently now, in other words, wants help for reading more infrequently." (parent AL/350)

The parents of those children who could move around independently guided and monitored their children until their youth. Independent moving was difficult because of difficulties in motor coordination or spatial conceptualization. Children needed help for example in following situations:

"Visits neighboring friends. Little by little learning to go further. Dangerous crossings and dark hours still worrying, is not always attentive. Gets easily lost in strange places." (parent AM/1422)

Because of their severe physical disability, children could not go home after school alone (which children in Finland usually do) but parents had to arrange care for them until they get home from work or if they wanted to take care of errands. Depending on disability, the child could need all-time monitoring and care.

“The child needs adult's presence and monitoring all the time." (parent AM/955)

Tantrums and other episodes of rage, defying, sticking to monotonous doing, and arguments with siblings were usual parts of everyday life. Parents often mentioned their children's behavioral problems in the data.

"The everyday life is hard, both parents' have shift work. The child has started the series of conniptions, wants to win away, and when one thing is settled the child comes up with a new one. Needs constant presence." (parent AM/514)

"Problems are caused by fatigue in weekdays, which comes out as crying, anger, and fallings at home. In addition, the child has pain/ache in neck, back, and legs.” (parent AM/6760)

Especially arguments with siblings were highlighted in parents' descriptions of everyday lives at home. The reason for these conflicts was, according to parents' perceptions, frustration because the child with disability was not able to do same things than other siblings who did not have disability.

Concern over the child's well-being were related to changes in ability to move around as the child grew bigger. In addition, waiting for operations and recovering from them influenced well-being. Children's difficulties in sleeping and bowel movement as well as overall coping worried parents. Many of them mentioned that they have to wake up several times at nights and, for example, needs for turning over their child when sleeping. Various aches and pain were also usual.

"Mentally doing ok. Physical state stable, except balance has gotten worse. Perhaps growth has influenced it." (parent AM/976)

“... situation with legs has gone worse, e.g., heels do not touch the floor when walking.” (parent $\mathrm{AM} / 249)$

“...wait times for operations, 'one's own misery'...” (parent AM/67)

"Doing otherwise well physically. It is just that the child has not been able to run without orthosis after the operation." (parent AM/331)

Children's sleep deprivation worried parents, too. Nights badly slept illustrate the demands the disability includes. They also tell about how situations can change as the child grows.

"Sometimes, the child has been waking up during nights, even four times a night. Often, the reason is that the child has not been able to turn because the bed board prevents it. The legs are 
so bent that the child has to be put straight in the middle of the bed. Otherwise turning over in any direction is impossible. Now, we have had a longer period that we have been able to sleep in peace." (parents AM/965)

"Waking up at night 3-10 times. The worst period is 00.30-2.30 am. During the day, the child is usually brisk and cheery. Big arguments when things do not go as the child wants (less frequently than before)." (parent AM/737)

Going to school, doing homework, remedial training, and for example standing in a standing rack (that is supposed to support physical well-being), hobbies and friend (or lack of them), time needed for rest, and needs for monitoring and assisting the child formed an entity that was unique in each family. They had to solve these demands in a best possible manner.

"There are not enough hours in a day to do everything. During weekdays after school, the child does not have energy to stand. Already doing homework takes about an hour and when considering dining and all, you do not have time to do everything in the evening. The child wants more free time, time to do nothing." (parent AL/416)

The way the everyday life was structured determined how fluent life was. On the other hand, the fluency of daily chores affected the daily life of all family members.

"The fluent daily life necessitates detailed structure and clear daily rhythm. The child still needs 12 hours of sleep which affects the family's everyday life." (parent AM/539)

The visible schedule for days and weeks and sticking to it were important means to make everyday life go as smoothly as possible. According to parents, some children seemed to be nervous about many forthcoming events, and therefore, they were not told about these events too much advance.

Furthermore, the disability could require repeated visits to hospital and parents had to arrange time for them from their work. Need for time to do everything made everyday life demanding. Worries about getting a school assistant or free time assistant increased challenges for their parts. Similarly, the deficiencies in the schools' physical environment, inaccessibility, concerned parents greatly. Also school commutes caused extra worries.

"Thinking about next year's schooling. Going to the school in the current school is not likely to be possible. The old school building is not accessible enough to the child. For example, there are plenty of stairs." (parent $\mathrm{AL} / 865)$

"There are problems with transportation. The current wheelchairs do not fulfill all safety criteria; therefore, transportation with a handicap bus has not been possible." (parent AT/965)

\subsection{Joys}

The everyday life as described by parents not only about challenges and worries but they mentioned various sources of joy, too. These could be categorized into five items: (1) the children themselves; (2) functional social relationships; (3) progress in learning and increasing skills; (4) well-being; and (5) functional environment, aids, and services.

The child brought joy to parents and people surrounding them. These notions reminded parents about the joys of parenting and appreciation of their children.

"The child is joyful and vivid." (parent $\mathrm{H} / 393$ )

“Everyday life goes on nicely. The child is still like happy sunshine." (parent AM/170)

Likewise, social relationships and friendships brought joy. The parents mentioned how important it was that their 
There are not enough hours in a day to do everything: Descriptions of everyday life with a child with disability

child got along with others and could create friendships.

"Gets along well with children and adults, has friends, and likes to play and bustle around with friends.” (parent AQ/455)

"Going to middle school has not influenced negative. Instead, the child has become a more determined student than before, does really well at school, and has good self-esteem. The child has found one good friend from the class." (parent AM/775)

The child with a severe physical disability may have to practice the basic skills of taking care of himself or herself for longer than children who are not restricted because of disability or inaccessible environment. Parents mentioned that learning to be more autonomous was a significant source of joy.

"The child has zest for knowing and learning, and has become more brisk in group situations. Increased initiative, lovely and happy child." (parent AN/37)

"Everyday life goes well; the child is already quite independent." (parent AM/33)

Progress in school and remedial training were mentioned in parents' descriptions. Positive attitudes to learning increased joy in everyday life. While physical disability caused numerous worries and difficulties and thus threatened well-being, parents remembered to be happy about times when things went well and smoothly.

"Everyday life goes well and therapy, too. The child is eager and industrious, goes to school and is active and participating." (parent AM/1462)

"During the past year, the child has been consciously handling the disability. Today, understands that disability is part of the life so that if something, e.g., physical activity is not possible, it is because of the disability and not because the child. And that there is nothing that the child can do about it. Now the child does not set the bar too high for task performances." (parent AM/157)

"The child is doing ok in my opinion. Everyday life as usual; recovering from ankle operation, which was in February. Had a cast for only 9 weeks!” (parent AM/96)

Social support in the form of support family and free time assistant were mentioned as factors that made everyday life easier. Likewise, if the home was renovated so that it was accessible, life had become easier. In all, getting an electric wheelchair or moped and transportation service caused joy because they provided the child a chance to move around independently.

“Life goes on as usual. Handicap renovation is now done at home.” (parent AM/1051)

\section{Conclusions}

Normal family life consists of various household chores, family members' mutual interaction, comings and goings, weekdays and vacations. A family with a child who has severe physical disability has a special rhythm in daily chores because the child needs constant care and monitoring, which is sometimes difficult to schedule. Parents' work, societal demands, and the child's special needs together are burdening and creating a daily structure that is functional requires time and effort from parents. Ability to be flexible and trust in positive development in the child and multi-professional collaboration are the keys. Parents have to remember to find joy from small successes and steps in progress. This study provided one description of how parents perceive their everyday lives with a child with severe physical disability. The study showed that home is a place where parents and children can be happy about little achievements and each other's proximity.

Everyday life consists of interaction with people and physical environment. When it comes to children with severe physical disability, daily events such as dining, going outdoors, sleeping, and common chores can be 
Häyrynen, E., Määttä, K., Äärelä, T., \& Uusiautti, S.

challenging because the child may not be able to use all aids or fully participate because of limitations in the environment.

The parents seemed to think that their core task is to support the child's school going and learning. Children were directed in activities that they are expected to learn and supported to learn behaviors and skills that they are expected to manage. It is crucial how the child is guided to independent activity: how much they are allowed to have responsibility and how they are encouraged to activity.

The emotional bond between a parent and a child is always strong but becomes emphasized when the child has physical disability. Participation and presence, care and encouragement by parents create the sense of security and being loved and cared for. Home environment allows space for conflicts and disagreements, too, because as problems are being solved and lessons are learned, children learn patience, empathy, and appreciation of other's opinions.

When evaluating the quality of this research, it is necessary to pay attention to the whole research process (Kvale \& Brinkmann, 2009). The data obtained from parents was abundant as it covered all 120 students in the remedial training period. The purpose of the forms that parents filled out was to get information about students' everyday life at home and school. This information helped tailoring the remedial training so that it would serve practical upbringing at home too. The core question is thus whether the data reliably described the students' learning environments. However, based on experiences from the remedial training in practice, the information was sufficient to support learning and activities in everyday life.

However, it is also worth noticing that there is not just one reality but according to constructivist conception of knowledge, events and situations appear differently to different people. Parents in this research have described their everyday life as they perceive it. These perceptions vary based on parents' own history, their experiences, and beliefs. On the other hand, every parent in this research knew that the forms were meant to use as tools for supporting families. Thus, everything mentioned in the forms are supposedly quite true and important in parents' opinions. Something may have left untold that was not possible to write in the form. It is difficult to evaluate what kind of information could have been reached with different kinds of questions and forms (see e.g., Denzin, 2012). In this research, the researchers' extensive familiarity with special education and research work helped interpreting and understanding the reality as described by parents (Cresswell, 2009).

\section{Discussion}

Home is the child's immediate environment as described, for example, by Bronfenbrenner's (2009) classic theory. According to it, the family forms a micro system and is in interaction with meso, exo, and macro systems. The child has the deepest, permanent, and continuing ties with the family, which is the daily environment for growth and development that takes care of the child's physical, psychological, and social needs.

The study showed that upbringing of a child with severe physical disability-like parenting in general—involves all kinds of challenges but also love and joy (Blacher et al,. 2013; Määttä \& Uusiautti, 2011). According to previous studies, having a child with disability may increase the sense of solidarity and strengthen family members' mutual relationships (Bayat, 2007). Parents have described how they have developed in patience, self-understanding, and personality and strengths (Hasting \& Taunt, 2002; Scorgie \& Sobsey, 2000). Similarly, a child with special needs can have a positive influence on siblings (O'Kane Grissom \& Borkowski, 2002). In addition, many mothers have experienced it rewarding to raise a child with disability (Green, 2007). The study at hand supports these findings.

Even though having a child with severe physical disability introduced special demands and challenges in everyday life at home, parenting is fundamentally similar to that of a so-called normal child. However, it is important to realize the special demands parents are faced and what kind of support they need to successfully raise their child with special needs. 
There are not enough hours in a day to do everything: Descriptions of everyday life with a child with disability

Collaboration with various professionals is an important part of everyday life. Schooling and remedial training and care may necessitate various kinds of support for parents. The need for support changes as the child is growing (Hetherington et al., 2010). Parents may also be concerned about their child's chances of becoming an active member of society and being able to influence of decision-making. The voices of people with disabilities are hardly heard but greatly needed in societal decision-making and promotion of equality (Cavet \& Sloper, 2004; Franklin \& Sloper, 2009). In the middle of busy daily chores, the parents can expected to just try to hear their child's voice (Cavet \& Sloper, 2004)—especially if considering the complicated and demanding special needs and communication problems children with severe physical disabilities may have (Häyrynen, Määttä, \& Uusiautti, 2018).

Although the nature of the parent-child relationship changes from early childhood to adolescence, the presence of warmth and sensitivity as well as support for autonomy as parenting behaviors appears to be critical to child well-being (Sheridan \& Burt, 2009). Positive caring supports children's cognitive development and social competence during the preschool years (Peisner-Feinberg, 2004).

Parents who are raising a child with severe physical disability need support (Kaiser \& Hancock, 2003). They also have to accept the uncertainty and moments of unsecurity in their parenting task. Therefore, it is important to remember that parents who want to raise children well do not have to be perfect people. The same concerns children: parents cannot expect children to be or become perfect either. When parents have faith in children's ability to develop and learn, it is easier for them to assure their children of it as well. Good parents are role models for children even in the most difficult life situations: they have to maintain the belief and pursue building better environment for children. Research like this helps to understand the everyday life in families from parents' perspective and finding ways of supporting them.

\section{References}

Bailey, D. B., Jr., Hatton, D. D., Mesibov, G., Ament, N., \& Skinner, M. (2000). Early development, temperament, and functional impairment in autism and fragile X syndrome. Journal of Autism and Developmental Disorders, 30(1), 49-59. https://doi.org/1023/A:1005412111706

Bailey, J. (2014). The history of mum and dad: Recent historical research on parenting in England from the 16th to 20th centuries. History Compass, 12(6), 489-507.

Bayat, M. (2007). Evidence of resilience in families of children with autism. Journal of Intellectual Disability Research, 51(9), 702-714. https://doi.org/10.1111/j.1365-2788.2007.00960.x

Bell, K. L., Boyd, R. N., Tweedy, S. M., Weir, K. A., Stevenson, R. D., \& Davies, P. S. (2010). A prospective, longitudinal study of growth, nutrition and sedentary behaviour in young children with cerebral palsy, BMC Public Health, 10(1), 179. https://doi.org/10.1186/1471-2458-10-179

Bennet, K. S., \& Hay, D. A. (2007). The role of family in the development of social skills in children with physical disabilities. International Journal of Disability, Development \& Education, 54(4), 381-397. https://doi.org/10.1080/10349120701654555

Beresford, B. (1996). Coping with the care of a severely disabled child. Health \& Social Care in the Community, 4(1), 30-40.

Bernheimer, L. P., \& Weisner, T. S. (2007). "Let me just tell you what I do all day...”: The family story at the center of intervention research and practice. Infants \& Young Children, 20(3), 192-201.

Bert, S. C., Farris, J. R., \& Borkowski, J. G. (2008). Parent training: Implementation strategies for adventures in parenting. The Journal of Primary Prevention, 29(3), 243-261.

Blacher, J., Begum, G. F., Marcoulides, G. A., \& Baker, B. L. (2013). Longitudinal perspectives of child positive impact on families: relationship to disability and culture. American Journal on Intellectual and Developmental Disabilities, 118(2), 141-155. https://doi.org/10.1352/1944- 7558-118.2.141

Bowlby, J. (1973). Attachment and loss: Separation, anxiety and anger. New York, NY: Basic Books.

Brannan, A. M., \& Heflinger, C. A. (2002). Distinguishing caregiver strain from psychological distress: Modeling the relationships among child, family, and caregiver variables. Journal of Child and Family 
Häyrynen, E., Määttä, K., Äärelä, T., \& Uusiautti, S.

Studies, 10, 405-418.

Bronfenbrenner, U. (2009). The ecology of human development: Experiments by nature and design. Cambridge, MA: Harvard University Press.

Cassidy, A., McConkey, R., Truesdale-Kennedy, M., \& Eamonn, S. (2008). Preschoolers with autism spectrum disorders: The impact on families and the supports available to them. Early Child Development and Care, 178(2), 115-128. https://doi.org/10.1080/03004430701491721

Cavet, J., \& Sloper, P. (2004). Participation of disabled children in individual decisions about their lives and in public decisions about service development. Children \& Society, 18(4), 278-290. https://doi.org/10.1002/CHI.803

Cen, S., \& Aytac, B. (2017). Ecocultural perspective in learning disability: family support resources, values, child problem behaviors. Learning Disability Quarterly, 40(2), 114-127.

Clark, S. C. (2000). Work/family border theory: a new theory of work/ family balance. Human Relations, 53, $747-770$.

Cresswell, J. W. (2009). Research design: qualitative, quantitative, and mixed methods approaches. Thousand Oaks, CA: Sage.

De Bortoli, T., Arthur-Kelly, M., Mathisen, B., Foreman, P., \& Balandin, S. (2010). Where are teachers' voices? A research agenda to enhance the communicative interactions of students with multiple and severe disabilities at school. Disability and Rehabilitation, 32(13), 1059-1072. https://doi.org/10.3109/09638280903410730

Denzin, N. K. (2012). Triangulation. 2.0. Journal of Mixed Methods Research, 8(2), 80-88. https://doi.org/10.1177/1558689812437186

Diamond, K. E., \& Hong, S.-Y. (2010). Young children's decisions to include peers with physical disabilities in play. Journal of Early Intervention, 32(3), 163-177. https://doi.org/10.1177/1053815110371332

Emerson, E., Hatton, C., Llewellyn, G., Blacker, J., \& Graham, H. (2006). Socioeconomic position, household composition, health status and indicators of the well-being of mothers of children with and without intellectual disabilities. Journal of Intellectual Disability Research, 50(12), 862- 873. https://doi.org/10.1111/j.1365-2788.2006.00900.x

Franklin, A., \& Sloper, P. (2006). Participation of disabled children and young people in decision-making within social services departments: a survey of current and recent activities in England. British Journal of Social Work, 36(5), 723-741. https://doi.org/10.1093/bjsw/bch306

Fuchs, R. G. (2004). Introduction to the forum on the changing faces of parenthood. Journal of Family History, 29(4), 331-338)

Glidden, L. M., \& Natcher, A. L. (2009). Coping strategy use, personality, and adjustment of parents rearing children with developmental disabilities. Journal of Intellectual Disability Research, 53(12), 998-1013. https://doi.org/10.1111/j.1365-2788.2009.01217.x

Graungaard, A. H., \& Skov, L. (2007). Why do we need a diagnosis? A qualitative study of parents' experiences, coping and needs, when the new born child is severely disabled. Child: Care, Health and Development, 33(3), 296-307

Green, S. E. (2003). "What do you mean 'what's wrong with her?": stigma and the lives of families of children with disabilities. Social Science \& Medicine, 57(8), 1361-1374. https://doi.org/10.1016/S0277-9536(02)00511-7

Green, S. E. (2007). "We're tired, not sad": Benefits and burdens of mothering a child with a disability. Social Science \& Medicine, 64(1), 150-163. https://doi.org/1060/j.socscimed.2006.08.025

Guest, E. M., \& Keatinge, D. R. (2009). The value of new parent groups in child and family health nursing. The Journal of Perinatal Education, 18(3), 12.

Hassal, R., \& Rose, J. (2005). Parental cognitions and adaptation to the demands of caring for a child with an intellectual disability: a review of the literature and implications for clinical interventions. Behavioral and Cognitive Psychotherapy, 33(1), 71-88. https://doi.org/10.1017/S135246580400178X

Hasting, R. P., \& Taunt, H. M. (2002). Positive perceptions in families of children with developmental disabilities. American Journal on Mental Retardataion, 107(2), 116-127. 
There are not enough hours in a day to do everything: Descriptions of everyday life with a child with disability https://doi.org/10.1352/0895-8017(2002)1072

Hastings, R. P., \& Brown, T. (2002). Behavior problems of children with autism, parental self-efficacy, and mental health. American Journal on Mental Retardataion, 107(3), 222-232

Häyrynen, E., Määttä, K., \& Uusiautti, S. (2018). "Let's let the student do by themselves". How to activate students with severe physical disability in the classroom. Journal of Social Sciences, 7(1), 28-41.

Hetherington, S. A., Durant-Jones, L., Johnson, K., Nolan, K., Smith, E., TaylorBrown, S., \& Tuttle, J. (2010). The lived experiences of adolescents with disabilities and their parents in transition planning. Focus on Autism and Other Developmental Disabilities, 25(3), 163-172. https://doi.org/10.1177/1088357610373760

Hinton, V. J., De Vivo, D. C., Fee, R., Goldstein, E., \& Stern, Y. (2004). Investigation of poor academic achievement in children with Duchenne muscular dystrophy. Learning Disabilities Research \& Practice, 19(3), 146-154. https://doi.org/10.1111/j.1540-5826.2004.00098.x

Kaiser, A. P., \& Hancock, T. B. (2003). Teaching parents new skills to support their young children's development. Infants \& Young Children, 16(1), 9-21.

Kvale, S., \& Brinkmann, S. (2009). InerViews. Learning the craft of qualitative research interviewing. Los Angeles, CA: Sage.

Määttä, K., \& Uusiautti, S. (2011). Pedagogical love and good teacherhood. In Education, 17(2). Retrieved from https://ineducation.ca/ineducation/article/view/81

Määttä, K., \& Uusiautti, S. (2012). Parental love - Irreplaceable for children's well-being. Global Journal of Human Social Science, 12(10), 1-8.

Määttä, K., \& Uusiautti, S. (2013). Many faces of love. Rotterdam: Sense Publishers.

Majnemer, A., Shevell, M., Law, M., Poulin, C., \& Rosenbaum, P. (2010). Level of motivation in mastering challenging tasks in children with cerebral palsy. Developmental Medicine \& Child Neurology, 52(12), 1120-1126. https://doi.org/10.1111/j.1469-8749.2010.03732.x

Mayring, P. (2000). Qualitative content analysis. Qualitative Social Research, 1(2). Retrieved from: http://www.qualitative-research.net/index.php/fqs/article/view/1089/2386

Miller, F., \& Bachrach, S. J. (2017). Cerebral palsy: A complete guide for caregiving. Baltimore: A Johns Hopkins University Press.

Miodrag, N., \& Hodapp, R. M. (2010). Chronic stress and health among parents of children with intellectual and developmental disabilities. Current Opinion in Psychiatry, 23(5), 407-411. https://doi.org/10.1097/YCO.0b013e32833a8796

Moat, S. J., Bradley, D. M., Salmon, R., Clarke, A., \& Hartley, L. (2013). Newborn bloodspot screening for Duchenne muscular dystrophy: 21 years experience in Wales (UK). European Journal of Human Genetics, 2l(10), 1049-1053. https://doi.org/10.1038/ejhg.2012.301

Mol, E. M., Monbaliu, E., Ven, M., Vergote, M., and Prinzie, P. (2012). The use of night orthoses in cerebral palsy treatment: Sleep disturbance in children and parental burden or not? Research in Developmental Disabilities, 33(2), 341-349. https://doi.org/10.1016/j.ridd.2011.10.026

Nereo, N. E., \& Hinton. V. J. (2003). Three wishes and psychological functioning in boys with Duchenne muscular dystrophy. Journal of Developmental and Behavioral Pediatrics, 24(2), 96-103.

Nowak, H. (2017). Parents of children with developmental disabilities and their experiences of formal support. (Doctoral Dissertation in Psychology. University of Gothenburg.)

O'Kane Grissom, M., \& Borkowski, J. G. (2002). Self-efficacy in adolescents who have siblings with or without disabilities. American Journal on Mental Retardation, 107(2), 79-90. https://doi.org/101352/0895-8017(2002)107

Peisner-Feinberg, E. S. (2004). Child care and its impact on young children's development. Encyclopedia on early childhood development. Centre of Excellence for Early Childhood Development. Retrieved from: http://www.childencyclopedia.com/documents/Peisner-FeinbergANGxp.pdf

Petersson, K., Petersson, C., \& Håkansson, A. (2004). What is good parental education? Scandinavian Journal of Caring Sciences, 18(1), 82-89.

Pirilä, S., van der Meere, J. J., Rantanen, K., Jokiluoma, M., \& Eriksson, K. (2011). Executive functions in youth 
Häyrynen, E., Määttä, K., Äärelä, T., \& Uusiautti, S.

with spastic cerebral palsy. Journal of Child Neurology, 26(7), 817-821. https://doi.org/10.1177/0883073810392584

Rentnick, I. C., Gorter, J. W., Ketelaar, M., Lindeman, E., \& Jongmans, M. J. (2009). Perceptions of family participation among parents of children with cerebral palsy followed from infancy to toddler hood. Disability \& Rehabilitation, 31(22), 1828-1834. https://doi.org/10.1080/09638280902822286

Scorgie, K., \& Sobsey, D. (2000). Transformational outcomes associated with parenting children who have disabilities. Mental Retardation, 38(3), 195-206. https://doi.org/10.1352/0047-6765(2000)0382.0.CO;2

Seltzer, M. M., Greenberg, J., Floyd, F., Pettee, Y., \& Hong, J. (2001). Life course impacts of parenting a child with a disability. American Journal on Mental Retardataion, 106(3), 265-286. https://doi.org/10.1352/0895-8017(2001)1062.0.CO;2

Shandra, C. L., \& Penner, A. (2017). Benefactors and beneficiaries? Disability and care to others. Journal of Marriage and Family, 29(4), 543-555.

Sheridan, S. M., \& Burt, J. D. (2009). Family-centered positive psychology. In S. J. Lopez \& C. R. Snyder (Eds.), Oxford library of psychology. Oxford handbook of positive psychology (pp. 551-559). New York, NY: Oxford University Press.

Singer, G. H. S. (2006). Meta-analysis of comparative studies of depression in mothers of children with and without developmental disabilities. American Journal on Mental Retardation, 111(3), 155-169.

Smith, T. B., Oliver, M. N. I., \& Innocenti, M. S. (2001). Parenting stress in families of children with disabilities. American Journal of Orthopychiatry, 71(2), 257-261

Stamann, C., Janssen, M., \& Schreier, M. (2016). Searching for the core: defining qualitative content analysis. Forum: Qualitative Social Research, 17(3), Art. 16, Retrieved from: http://www.qualitative-research.net/index.php/fqs/issue/view/56

Starke, M., \& Möller, A. (2002). Parents' needs for knowledge concerning the medical diagnosis of their children. Journal of Child Health Care, 6(4), 245-257.

Summers, J. A., Marquis, J., Mannan, H., Turnbull, A., Fleming, K., Poston, D. J., \& Kupzyk, K. (2007). Relationship of perceived adequacy of services, 59 family-professional partnerships, and family quality of life in early childhood service programmes. International Journal of Disability, Development and Education, 54(3), 319-338. https://doi.org/10.1080/10349120701488848

Swain, P. A., \& Cameron, N. (2003). 'Good Enough Parenting': Parental disability and child protection. Disability \& Society, 18(2), 165-177

Tudge, J. (2008). The everyday lives of young children: Culture, class, and child rearing in diverse societies. Cambridge: Cambridge University Press.

Veríssimo, M., Santos, A. J., Vaughn, B. E., Torres, N., Monteiro, L., \& Santos, O. (2011). Quality of attachment to father and mother and number of reciprocal friends. Early Child Development and Care, 181(1), 27-38.

Wadnerkar, M. B., Pirinen, T., Haines-Bazrafshan, R., Rodgers, J., \& James, D. (2012). A single case study of a family-centred intervention with a young girl with cerebral palsy who is a multimodal communicator. Child: Care, Health \& Development, 38(1), 87-97. https://doi.org/10.1111/j.1365-2214.2011.01214.x

Wallander, J. L., \& Varni, J. W. (1998). Effects of pediatric chronic physical disorders on child and family adjustment. Journal of Child Psychology and Psychiatry, 39(1), 29-46. 